\title{
The construction of ethical \\ competence in the perception of primary care nurses*
}

\author{
A CONSTRUÇÃO DA COMPETÊNCIA ÉTICA NA PERCEPÇÃO DE ENFERMEIROS DA \\ ATENÇÃO PRIMÁRIA
}

\section{LA CONSTRUCCIÓN DE LA COMPETENCIA ÉTICA EN LA PERCEPCIÓN DE ENFERMEROS DE LAATENCIÓN PRIMARIA}

\author{
Rafaela Schaefer ${ }^{1}$, José Roque Junges ${ }^{2}$
}

\begin{abstract}
The study intended to understand the perception of nurses of Primary Care Services about the construction of ethical competence on their formation and practices. This is a qualitative study, with an interpretative phenomenological approach and interviews with ten nurses of the community health services of Porto Alegre, RS. The results showed that the interviewed professionals had already experienced situations with ethical conflicts and knew what ethical competence means. The central themes point out three fundamental issues in the construction of the ethical competence: personal values, education and practice. Taking into account that ethical competence is in permanent construction, the study shows the importance to promote organizational and educational activities in a transversal manner, as a tool to cope the moral stress and contribute in improving the quality of care in the primary health attention.
\end{abstract}

\section{DESCRIPTORS}

Primary Health Care

Nursing care

Ethics, nursing

Education, nursing

\section{RESUMO}

O estudo buscou entender a percepção de enfermeiros da atenção primária sobre a construção da competência ética. A pesquisa foi qualitativa, de cunho fenomenológico interpretativo, tendo sido realizadas entrevistas com 10 enfermeiros de serviços de atenção primária de Porto Alegre, RS. Os resultados mostram que os profissionais entrevistados já haviam vivenciado situações eticamente conflitivas e tinham domínio da definição de competência ética. Os temas centrais apontam para três pilares fundamentais na construção da competência ética: os valores pessoais, o ensino e a prática. Tendo presente que a competência ética é algo em permanente construção, o estudo mostra a importância de promover iniciativas educacionais e organizacionais de forma transversal, como ferramenta de enfrentamento do stress moral e contribuir para melhorar a qualidade do cuidado em atenção primária à saúde.

\section{RESUMEN}

Estudio cualitativo con abordaje fenomenológico interpretativo cuyo objetivo fue entender la percepción de los enfermeros de atención primaria sobre la construcción de la competencia ética en su formación y práctica. Se llevaron a cabo entrevistas a 10 enfermeros de distintos servicios de atención primaria de Porto Alegre, RS. Los resultados demostraron que los profesionales entrevistados ya habían vivido situaciones éticamente conflictivas y conocían el significado de competencia ética. Los temas centrales apuntaron hacia tres pilares fundamentales en la construcción de la competencia ética: los valores personales, la enseñanza y la práctica. Teniendo en cuenta que la competencia ética está en permanente construcción, el estudio muestra la importancia de promover transversalmente iniciativas educacionales y organizacionales, así como herramientas del enfrentamiento del estrés moral y contribuye a mejorar la calidad del cuidado en la atención primaria en salud.

\author{
DESCRITORES \\ Atenção Primária à Saúde \\ Cuidados de enfermagem \\ Ética em enfermagem \\ Educação em enfermagem
}

\footnotetext{
*Extracted from the dissertation "The construction of ethical competence in primary care: the case of nursing", Universidade do Vale do Rio dos Sinos, 2012. ${ }^{1}$ MSc in Public Health at the Postgraduate Program of Community Health, Universidade do Vale do Rio dos Sinos, São Leopoldo, RS, Brazil. rafaelaschaefer@hotmail.com 22 Professor and Researcher, Postgraduate Program of Community Health, Universidade do Vale do Rio dos Sinos, São Leopoldo, RS, Brazil.

$\begin{aligned} \text { Rev Esc Enferm USP } & \text { Received: } 10 / 22 / 2013 \\ \text { 2014; 48(2):324-8 } & \text { Approved: } 12 / 26 / 2013\end{aligned}$
}




\section{INTRODUCTION}

In the universe in constant renewal, the changes in the field of the health policies and practices in Brazil are noteworthy. Movements such as the Brazilian Health Reform (Reforma Sanitária Brasileira)(1), lead the country to overcome the assistance model and enter the field of preventive actions, leading to the reflection about the daily lives of primary health care services (PHC) and training of professionals ${ }^{(2)}$.

Important changes in the political arena of the country have raised the issue of proposals for decentralization of health services and recovery of $\mathrm{PHC}^{(2)}$. This restructuring scenario transformed the practice and roles of professionals ${ }^{(2-3)}$ and brought to the health agenda the discussion of topics such as the ethical dimension of work ${ }^{(4)}$.

The rise of chronic and complex diseases and aging populations have significantly increased the number of visits to PHC services. In 2010, in Brazil, there were already approximately 30,000 family health teams serving approximately 98 million people ${ }^{(1)}$. In special, there was a substantial increase in responsibilities of nurses in these services. In addition, more and more users leave the passive posture of care recipients, to participate in the decision-making process in health, which creates new demands from an ethical point of view ${ }^{(5)}$.

This new organization of the care setting reveals the importance of discussing ethical competence in health ${ }^{(5)}$. The importance of PHC in the health policy of the country requires direct efforts to identify difficulties and potentialities in the work of professionals acting in it.

Professional competence is defined as the ability to mobilize and articulate knowledge and values, integrating the knowledge in the daily process of knowing what to do, which confers results on actions ${ }^{(6)}$. The meaning of being ethically responsible is dealing with the ethical demand in a critical, reflective and resolutive manner ${ }^{(7)}$.

The concern with the context of changes in the profession of nursing can be perceived both in education and the practice. The National Curriculum Guidelines for Undergraduate Nursing (Res CNE/CES № 03) ${ }^{(8)}$ were approved in education with the objective of responding to the needs to train more critical and reflective practitioners, incorporating ethics transversely throughout the education process, which still represents a challenge ${ }^{(9)}$. In practice, seminars, discussion groups and areas of continuing education can be observed, aiming to increasingly qualify services and nursing professionals ${ }^{(10)}$.

Studies on this topic can be identified in the scientific bases ${ }^{(7,11)}$, and many address the ethical competence in teaching ${ }^{(12-13)}$. Few develop the theme of ethical competence in $\mathrm{PHC}$, which shows the lack of production in this scenario.
The aim of the study was to understand the perceptions of PHC nurses on the construction process of ethical competence.

\section{METHOD}

This is a qualitative study, based on interpretative phenomenology, which seeks to understand and explore the experiences of people's lives, investigating subjective phenomena. Phenomenological research tends to be developed with small samples, of about 10 participants or less, since everyone has to experience the phenomenon under study. In this case, participants who have experienced ethical issues in their professional practice and who are able to express the meaning of having lived this experience ${ }^{(14)}$.

Ten nurses working in the Department of Community Health (SSC) of the Grupo Hospitalar Conceição (GHC) were interviewed. This is a federal public institution located in Porto Alegre and linked to the Ministry of Health. The SSC was established in 1982 to train human resources in the field of Family Medicine and nowadays is a network of 12 health centers serving approximately 100 thousand people. The justification for the choice of this service is based on the fact that it is a reference PHC service and pioneer in the restructuring of the Brazilian healthcare model ${ }^{(15)}$.

In order to enrich the methodological assumption, a questionnaire was applied to all nurses SSC workers who agreed to participate, with the aim of identifying those who had already experienced the subject of study in their work practice. In each health facility, a nurse was asked to answer a semistructured interview that addressed the issue of ethical competence. Such interview was based on examples of ethically conflicting cases, the nurse's perception of ethical competence, experienced difficulties and challenges, resources used to solve the more complex cases and what is considered important to be done in order to facilitate the construction of ethical competence.

Data collection was carried out between the months of December/2011 and March/2012. The collected data were digitally recorded, transcribed and analyzed following the steps of interpretative phenomenological analysis ${ }^{(14)}$, namely: reading of interviews in search for a general understanding; development of interpretive summaries of each interview, request for another researcher to analyze the interviews and then go back to the text and search for possible interpretive disagreements; identification of common meanings and shared practices, leaving relationships between subjects emerge; and finally, a presentation of the final draft of the themes found, along with example excerpts.

The study was carried out in accordance with the ethical standards recommended by the Resolution 196/96 of the National Council of Ethics in Research and approved by the Ethics Committee in Research of the Grupo Hospitalar 
Conceição (no. 11-111/August, 2011). All the participants signed an Informed Consent Form.

\section{RESULTS}

Survey participants were mostly women, aged between 35 and 62 years and who had been working in PHC services for 10 years, on average.

The reading of interviews sought a general understanding of the findings and showed that all respondents mentioned having already experienced some ethically conflictive situation at work in the PHC:

For me a good example was the gentleman who had an amputation (...) He is cared for by two daughters (...) one of the daughters said she had been abused in childhood (...) and the offender is this gentleman. It was a situation in which I had to reflect on what would be more ethical (E.3).

The interviewees also agreed on what they understood by ethical competence:

The ethically competent nurse is the one who can accommodate the demand $(\ldots)$ reflect $(\ldots)$ think together with the staff and with the own person (...) what will be best at that moment (E.5)

The interpretative summaries allowed to reach common meanings and shared practices among the different professionals, giving rise to three central themes in the construction process of ethical competence: personal values, education and practice:

For me one thing comes from upbringing, the ethical issue the other one is that we have formal education (...) and within day-to-day work we also perceive ourselves (...) the day-to-day gives us experience (E.4).

All the time you're faced with actions in which you need to have a line of thought, a line of conduct and it has to be what you learned, what you read and what the practice taught you (E.6).

Personal values were related to education and teaching arising from family relationships and social life, i.e., life experiences:

A lot comes from personal and family education, from childhood and upbringing, we come with what has been built since childhood. We reflect this in the practice (E.2).

The issue of education was very present in the speeches. The subjects mentioned the importance of studying ethics for the construction of ethical competence:

(...) there is the part of formal training, which is the education we have at university and that I guess so, it interferes (...) that you will use to make your decisions and that is the more theoretical part (E.5).

For the interviewees, the practice scenario is the main area of construction of ethical competence. It is when professionals are faced with the problem, assume responsibility for solving it and take their actions grounded in values and knowledge:

The practice shows concrete situations (...) you have a human being in front of you (...). The nurses have to be able to bring all the support and base that they have for the moment and, be able to use this tool (E.8).

The professionals have made reference to a gap between the themes in teaching and in practice:

The theory says one thing and in practice we see another thing (E.6)

The subjects also highlighted the fact that being ethically competent is being in constant construction:

We do not come ready from university and we are never ready. We're always in constant construction and reconstruction (E.5)

\section{DISCUSSION}

In PHC services, ethical issues are present on the dayto-day work of nurses ${ }^{(16-17)}$. The difficulties to deal with growing ethical demands are great and result from the provision of care from the perspective of the whole ${ }^{(3)}$. A study ${ }^{(18)}$, however, contradicts this assertion when saying that nurses of PHC services do not experience as many ethical issues as the literature indicates. In this respect, the author warns to the subtlety of the ethical problems of this reality, which can be complex, difficult to define and recognize. Some authors $^{(16)}$ corroborate this view, stating that the ethical problems in PHC reflect concerns of daily life and are less dramatic, which does not mean they are less important.

Unidentified and unresolved ethical problems can cause symptoms of moral stress, such as dissatisfaction, anger, isolation, anxiety, depression, job change or even abandonment of the profession ${ }^{(19)}$. The experience of ethically conflict situations seems inevitable in nursing, however, measures can be taken to improve the ability of professionals to positively deal with ethical proble$\mathrm{ms}^{(20)}$. The ethical competence can represent this tool, since it aims to associate the technical knowledge with critical reflection in the process of coping with difficult ethical issues ${ }^{(11)}$.

Most nurses have knowledge of their ethical competence, feel prepared to deal with the problems and are confident about their ethical practice ${ }^{(21)}$. However, it is not always enough to know what ethical competence means, it must be put into practice ${ }^{(11)}$. In this context, the three pillars of the construction process of ethical competence - personal values, education and practice - may represent a path.

The first relates to personal values, results from family teachings and social life, which are typical of a
The construction of ethical competence in the perception of primary care nurses Schaefer $R$, Junges JR 
particular culture and make that each professional has different ways of perceiving the same situations and, therefore, think of different alternatives for coping ${ }^{(10)}$. The literature supports this statement and adds that culture can affect the ethical decision-making of nurses ${ }^{(21-22)}$.

Increasing spaces of dialogue for discussing ethics and values can be an important strategy for nurses, to share their individual visions and build a collective decision in teamwork ${ }^{(17)}$. This process of critical reflection, based on the values, is one of the cornerstones of ethical competence and can help professionals to deal with ethical issues in a positive way, which will certainly be reflected in the quality of care ${ }^{(11)}$.

Regarding the second - education - initiatives to form professionals can be observed, in a way that they recognize the social determinants of health, are critical and reflective in decision-making and protagonists of completeness. The approval of the DCN/ENF well exemplifies this concern ${ }^{(8)}$. Studies show that ethical education can be a promoter of competence and that discussing it during training helps the process of forming more secure professionals who are prepared to deal with ethical problems ${ }^{(10-11)}$. Besides the discussion, the spaces of practical experience during undergraduate years are also important means of building competence, as it is when students experience situations of ethical conflict that go beyond theory ${ }^{(12)}$.

However, the reality with which the practitioner is faced when getting to health services is not necessarily what has been presented in the classroom ${ }^{(9)}$. There is a gap between theory and practice that might never be filled, because experiencing problem situations as a student will always be different than experiencing similar situations as a professional. Thus, the focus for the development of ethical competence may be beyond study, requiring attention from health institutions ${ }^{(4)}$.

From the perspective of the third value - the practice - the strategies used by nurses to cope with ethical problems are based on previous experiences ${ }^{(23)}$. However, even experienced nurses continue to express the need to develop their ethical competence ${ }^{(24)}$. This finding shows that, beyond individual experience, it may be necessary to emphasize the organizational aspects of practice in order to make workplaces more consistent from the ethical point of view ${ }^{(4)}$.

A favorable ethical climate in health institutions means professional fields with opportunities for involvement of the nurses in decisions, ethical support by management, search for good working relationships with colleagues, managers and patients and adequacy of health policies and practices. The organizational culture may be a facilitator or inhibitor of the construction of ethical competence when turning (or not) the attention to initiatives that provide a favorable ethical environment, providing tools for professionals to develop their skills and abilities ${ }^{(25)}$.
In search of a favorable ethical climate, the PHC services may resort to different strategies, thought from problems that professionals experience in their daily lives. An example might be the development of continuing education programs, focused on to the discussion of ethics. The goal would be to provoke reflection and critical thinking on the way workers think and act in their professional context, when looking for alternatives in the assistance, discussed with the team. The model of permanent education where learning is embedded in the daily practice, enables workers to develop skills because it turns them into protagonists and subjects of the working processes ${ }^{(26)}$.

Assuming that ethical competence is a process in permanent construction, the model of permanent education seems to respond well to this need. Through this methodology it is possible to work with different strategies, depending on the objectives of each institution. It is important to be aware of the fact that interventions, regardless of their nature, will only be effective if the ethical dimension of the organization itself is also developed ${ }^{(11)}$.

\section{CONCLUSION}

We live in a time of profound change in the fields of politics, education and health, which require responses of the work in health and of the education to this work. It is necessary to constantly seek to know, reflect and improve the health context in the country.

The results of this study showed that all the interviewed nurses had experienced situations of ethical conflict in their work, expressing knowledge about the definition of ethical competence. The nurses felt that the personal values, education and practice are the pillars that support the building of an ethically competent professional. With this identification, it is possible to direct efforts to assist nurses in competently dealing with the growing ethical demand in these services.

The evidence presented by the participants, that ethical competence is something that is always under construction, shows that actions focused on ethics should be constant and transversal. Both at the level of education and the practice, since ethical competence is an important tool in coping with difficulties that may result from this context, as the moral stress, for example.

This study does not intend to respond to all the challenges involved in the formation of ethically competent professionals, nor end the discussion on the topic. Its goal was to present the way the nurses perceive the process of construction of ethical competence to identify where this issue can be more effectively developed. Its findings open a space for educational and organizational initiatives that can promote the construction of ethical competence, reflecting in the quality of care. 


\section{REFERENCES}

1. Paim J, Travassos C, Almeida C, Bahia L, Macinko J. O sistema de saúde brasileiro: história, avanços e desafios. The Lancet Saúde no Brasil [Internet]. 2011 [citado 2012 jun. 24]. Disponível em: http://download.thelancet.com/flatcontentassets/pdfs/brazil/brazilpor1.pdf

2. Favoreto CAO. A prática clínica e o desenvolvimento do cuidado integral à saúde no contexto da atenção primária. Rev APS. 2008;11(1):100-108.

3. Matumoto S, Fortuna CM, Kawara LS, Mishima SM, Pereira MJB. Nurses' clinical practice in primary care: a process under construction. Rev Latino Am Enferm. 2011; 19(1):123-30.

4. Lunardi VL, Barlem ELD, Bulhosa MS, Santos SSC, Lunardi FiIho WD, Silveira RS, et al. Sofrimento moral e a dimensão ética no trabalho da enfermagem. Rev Bras Enferm. 2009; 62(4):599-603.

5. Maestro FJ, Martinez-Romero M, Vazquez-Naya JM, Pereira $\mathrm{J}$, Pazos A. Ethical and legal issues in the clinical practice of primary health care. Front Biosci. 2013;5:435-45.

6. Le Boterf G. Desenvolvendo a competência dos profissionais. Porto Alegre: Artmed; 2007.

7. Paganini MC, Egry EY. The ethical component of professional competence in nursing: an analysis. Nurs Ethics. 2011;18(4):571-82.

8. Brasil. Ministério da Educação; Conselho Nacional de Educação, Câmara de Educação Superior. Resolução CNE/CES n. 3, de 7 de novembro de 2001. Institui as Diretrizes Curriculares Nacionais do Curso de Graduação em Enfermagem [Internet]. Brasília; 2001 [citado 2012 jun. 24]. Disponível em: http://portal.mec.gov.br/cne/arquivos/pdf/CES03.pdf

9. Fernandes JD, Silva RMO, Teixeira GA, Florencio RMS, Silva LS, Rebouças LCC. Aderência de cursos de graduação em enfermagem às diretrizes curriculares nacionais na perspectiva do SUS. Esc Anna Nery Rev Enferm. 2013;17(1):82-9.

10. Bordignon SS, Lunardi VL, Dalmolin GL, Tomaschewski JG, Lunardi Filho WD, Barlem ELD, et al. Questões éticas do cotidiano profissional e a formação do enfermeiro. Rev Enferm UERJ. 2011;19(1):94-9.

11. Kälvemark Sporrong S, Arnetz B, Hansson MG, Westerholm $P$, Höglund AT. Developing ethical competence in health care organizations. Nurs Ethics. 2007;14(6):825-37.

12. Ramos FRS, Brehmer LCF, Vargas MAO, Schneider DG, Drago LC. Ethics constructed through the process of nurse training: conceptions, spaces and strategies. Rev Latino Am Enferm. 2013; 21(n.spec):113-21.

13. Burgatti JC, Leonello VM, Bracialli LAD, Oliveira MAC. Estratégias pedagógicas para o desenvolvimento da competência ético-política na formação inicial em Enfermagem. Rev Bras Enferm. 2013;66(2):282-6.
14. Polit DF, Beck CT. Fundamentos de pesquisa em enfermagem: avaliação de evidência para a prática da enfermagem. Porto Alegre: Artmed; 2011.

15. Grupo Hospitalar Conceição. Atenção à Saúde [Internet]. Porto Alegre; 2012 [citado 2012 jun. 24]. Disponível em: http://www.ghc.com.br/default.asp?idMenu=atencao_saude

16. Zoboli ELCP, Fortes PAC. Bioética e atenção básica: um perfil dos problemas éticos vividos por enfermeiros e médicos do Programa Saúde da Família, São Paulo, Brasil. Cad Saúde Pública. 2004;20(6):1690-99.

17. Lillemoen L, Pedersen R. Ethical challenges and how to develop support in primary health care. Nurs Ethics. 2012;20(1):96-108.

18. Laabs C. Moral problems and distress among nurse practitioners in primary health care. J Am Acad Nurs Pract. 2005;17(2):76-84.

19. Cronqvist A, Nyström M. A theoretical argumentation on the consequences of moral stress. J Nurs Manag. 2007;15(4):458-65.

20. Eizenberg MM, Desivilya HS, Hirschfeld MJ. Moral distress questionnaire for clinical nurses: instrument development. J Adv Nurs. 2009;65(4):885-92.

21. Grady C, Danis M, Soeken KL, O'Donnell P, Taylor C, Farrar $A$, et al. Does ethical education influence the moral action of practicing nurses and social workers? Am J Bioeth. 2008;8(4):4-11.

22. Cerit B, Dinç L. Ethical decision-making and professional behavior among nurses: a correlational study. Nurs Ethics. 2012;20(2):200-12.

23. Slettebo A, Haugen Bunch E. Ethics in nursing homes: experience and casuistry. Int J Nurs Pract. 2004;10(4):159-65.

24. Andrews DR. Fostering ethical competency: an ongoing staff development process that encourages professional growth and staff satisfaction. J Contin Educ Nurs. 2004;35(1):27-33.

25. Pauly B, Varcoe C, Storch J, Newton L. Registered nurses' perceptions of moral distress and ethical climate. Nurs Ethics. 2009;16(5):561-73.

26. Brasil. Ministério da Saúde; Secretaria de Gestão do TrabaIho e da Educação na Saúde, Departamento de Gestão da Educação em Saúde. Política Nacional de Educação Permanente em Saúde [Internet]. Brasília; 2009 [citado 2012 jun. 24]. Disponível em: http://bvsms.saude.gov.br/bvs/publicacoes/politica_nacional_educacao_permanente_saude.pdf 